\title{
RESENHA
}

\section{CONDÉ, Mauro Lúcio Leitão (org.) Ludwik Fleck: estilos de pensamento na ciência. Belo Horizonte: Fino Traço, 2012. 160 p.}

LETÍCIA ALVES VIEIRA

Universidade Federal de Minas Gerais

O presente livro de coletâneas sobre Ludwik Fleck foi organizado por Mauro Lúcio Leitão Condé ${ }^{1}$ por ocasião do I Colóquio de História e Filosofia da Ciência [Ludwik Fleck] da UFMG, o qual ocorreu no ano de 2010. Nessa coletânea de sete capítulos, quatro conferências do referido Colóquio foram transformadas em capítulos.

O livro se destina a um público interessado na obra, vida e contribuição das ideias de Fleck, e de sua importante obra Gênese e desenvolvimento de um fato científico, escrito por especialistas brasileiros e estrangeiros que estão preocupados com a difusão do conhecimento desse pensador polonês, que à sua época modificou pensamentos e práticas científicas, e que ainda hoje é atual.

Da orelha do livro, o organizador destaca uma breve biografia de Ludwik Fleck e ressalta que as reflexões de caráter filosófico e sociológico de Fleck, que foram publicadas em seu livro Gênese e desenvo/vimento de um fato científico, de 1935, e em alguns poucos artigos, têm sido utilizadas por diversos campos de conhecimento. Finaliza resumindo o pensamento fleckiano, que é diferente do pensamento de outros teóricos, como Kuhn, pois Fleck acredita que "o conhecimento não avança por meio de rupturas e sim de modo incremental, quando ações e ideias trafegam de diferentes modos entre estilos de pensamento criados pelos diferentes coletivos de pensamento" (CONDÉ, 2012).

Na Apresentação, o organizador apresenta o livro, ressaltando a biografia de Fleck e sua contribuição para vários campos de conhecimento, destacando a ênfase na dimensão social do conhecimento, bem como nas dinâmicas de práticas em contexto, e as implicações políticas advindas de sua afirmação do caráter democrático do conhecimento.

Após a publicação da obra principal de Ludwik Fleck, Gênese $e$ desenvo/vimento de um fato científico, em português, no ano de 2010, a

\footnotetext{
1 Mauro Lúcio Leitão Condé é professor associado de História e Filosofia da Ciência na Universidade Federal de Minas Gerais (UFMG). Doutor em Filosofia pela UFMG, Pós-Doutor pela Boston University. Coordenador do Scientia - Grupo de Teoria e História da Ciência da UFMG. Autor e organizador de livros em história e filosofia da ciência, além de autor de artigos publicados em periódicos especializados.
} 
presente publicação é a primeira em português que analisa a obra do pensador polonês, tendo sido escrita por especialistas brasileiros e estrangeiros. Isso demonstra o grande interesse da comunidade acadêmica nacional e internacional pelo pensamento desse autor.

Visando a uma melhor divulgação e visibilidade dos textos e da competência dos autores dessa coletânea, segue-se a listagem dos sete capítulos que a compõem: Capítulo 1 - Fleck em seu tempo, Fleck em nosso tempo: Gênese e desenvolvimento de um pensamento - Ilana Löwy; Capítulo 2 - Ludwik Fleck - Sua vida e Obra - Johannes Fehr; Capítulo 3 - Mannheim, Fleck e a compreensão humana do mundo - Carlos Alvarez Maia; Capítulo 4 - Ciência e linguagem: Ludwik Fleck e Ludwig Wittgenstein - Mauro Lúcio Leitão Condé; Capítulo 5 - Fato e pensamento em Ludwik Fleck e Walter Benjamin - George Otte; Capítulo 6 - Os circuitos de Fleck e a questão da popularização da ciência - Bernardo Jefferson de Oliveira; e Capítulo 7 - Escrever a história para ver e aprender a perguntar: a indefinição e a história da medicina reprodutiva (um esboço) - Martina Schlünder.

A obra se insere no contexto da historiografia da ciência ao debater questões relativas à comunidade científica, bem como às práticas dessa comunidade, e os desdobramentos advindos dessas ideias que são veiculadas pelos pesquisadores convidados a escrever sobre a temática.

As questões levantadas por Fleck dizem respeito aos estilos de pensamento que são criados por diferentes coletivos de pensamento, pois para ele, essas mudanças são gradativas, diferindo assim do conceito de revolução de Thomas Kuhn.

A partir da leitura dessa obra, o leitor perceberá as grandes possibilidades do uso da obra de Fleck não apenas no domínio das ciências, mas também das artes, da política e gestão, entre outras áreas de conhecimento. As contribuições de Fleck se inserem na dimensão social do conhecimento com foco na dinâmica das práticas científicas em um contexto, além das implicações políticas, visto que o campo da pesquisa é permeado por questões além de científicas: econômicas, principalmente nos dias atuais.

Em suas análises, os autores utilizaram como fio condutor a biografia de Fleck e suas contribuições para a ciência, no caso, em sua especialidade primeira, a medicina. Esse esforço de escrita foi realizado após a publicação em português da obra magna de Fleck - Gênese e desenvolvimento de um fato científico em 2010, e agora o leitor brasileiro é agraciado com mais uma obra em português que realiza uma análise da obra do pensador polonês.

Percebemos, através da exposição das temáticas presentes na publicação que ora resenhamos, que mesmo na sua pluralidade de assuntos, essas temáticas trazem o fio condutor da análise e aplicação da obra de Fleck como proposta pertinente tanto no âmbito teórico quanto metodológico para os interessados no estudo do pensamento desse grande autor polonês ainda pouco explorado.

Trata-se de uma iniciativa coletiva louvável e que vai de encontro às tendências da ciência no momento atual, pautando-se pelo trabalho coletivo e com objetivo de disseminar conhecimento para um público interessado nessas questões. 
Enfim, a presente obra é de interesse não apenas para historiadores, e seu conteúdo traz para o debate historiográfico atual, questões pertinentes à ciência e a todos os desdobramentos advindos das práticas científicas de seus participantes. Ressaltamos que a obra cumpriu seu papel de disseminação do pensamento fleckiano entre os leitores brasileiros e tem uma escrita clara e concisa, incluindo os capítulos que foram traduzidos.

Recomenda-se a leitura para todos aqueles que estão interessados em novas aplicações de metodologias e em avançar no debate historiográfico acerca da comunicação científica e comunidade científica.

\section{Agradecimentos}

Esta resenha é resultado da oficina na disciplina "Produção e circulação do conhecimento histórico nos periódicos científicos: análises, desafios e práticas de publicação" no $2^{\circ}$ semestre/2012, ministrada pela Profa. Regina Horta Duarte no Programa de Pós Graduação em História da Faculdade de Filosofia e Ciências Humanas da UFMG. Agradeço aos colegas pelos debates e revisões dos textos. 